\title{
KONSUMERISME PREWEDDING \\ (Strategi Komunikasi Bisnis Industri Foto Prewedding)
}

\author{
Ariesta Amanda \\ UNU Purwokerto \\ a.amanda@unupurwokerto.ac.id
}

\begin{abstract}
ABSTRAK
Penelitian ini bertujuan untuk mengkritisi fenomena foto prewedding sebagai salah satu tren yang kini mempunyai massa. Penelitian ini menggunakan metode kualitatif dengan dengan didukung kajian literatur yang berlokasi di Yogyakarta. Data diperoleh melalui observasi dan wawancara dengan pelaku industri foto prewedding, pelaku prewedding, dan masyarakat. Analisis data yang dilakukan meliputi pengumpulan data, triangulasi, penyajian data, dan penarikan kesimpulan. Hasil penelitian ini menunjukkan bahwa kehadiran tren foto prewedding tidak terlepas dari pelebaran bisnis foto pernikahan. Para pelaku industri foto menawarkan media representasi yang mampu membentuk wujud kesempurnaan diri serta mampu memfasilitasi ruang privat dalam wujud foto prewedding dengan menggunakan strategi komunikasi bisnis untuk menarik massa. Mix strategi yang dilakukan yaitu dengan menggunakan media sosial sebagai pendukung dalam pemasaran foto prewedding. Perspektif ekonomi industri foto melihat pasangan calon pengantin sebagai komoditas. Foto prewedding mampu meleburkan kelas sosial dalam masyarakat dan merubah sistem nilai tradisional masyarakat dengan jalan memanipulasi perspektif dalam melihat dirinya dalam sebuah bingkai foto.
\end{abstract}

Kata Kunci : strategi komunikasi bisnis, konsumerisme, prewedding 


\section{Pendahuluan}

Awal abad 21 foto prewedding mulai masuk ke Indonesia dan terus berkembang hingga menjadi suatu tren yang seakan wajib dilakukan oleh calon pengantin, di kotakota besar sebelum melangsungkan pernikahannya. Kemunculan foto prewedding ini tidak lepas dari pengaruh berkembangnya industri foto pernikahan (foto wedding) di masyarakat sebagai lahan bisnis yang menguntungkan. Dugaan ini sejalan dengan pendapat yang dinyatakan oleh O'brein (1995: 27), yang menyatakan bahwa hampir sebagaian besar fotografer prefesional di era modern, pekerjaan utamanya adalah memotret kegiatan sosial bernama pernikahan. Jumlah konsumen yang besar berdampak pada skala peredaran uang yang sama besarnya pada industri foto pernikahan. Pengaruh dari bayangan keuntungan yang ditawarkan oleh industri itu merambah pada peningkatan persaingan di kalangan produsen foto untuk menjaring konsumen.

Di jaman era globalisasi saat ini, keberadaan informasi menjadi hal yang penting, bahkan diakui bahwa informasi bisa dijadikan komoditi yang turut diperhitungkan dalam penentuan kebijakan dan dasar bisnis ekonomi perusahaan. Penyaluran informasi berjalan dengan adanya aktivitas komunikasi yang dilakukan manusia, baik secara sengaja atau tidak. Keberhasilan berkomunikasi selama ini sangat ditentukan oleh teknik pengelolaan pesan yang menarik dan diasosiasikan sebagai usaha pihak si komunikator. Komunikasi diartikan sebagai proses dalam penyaluran informasi atau pesan melalui sarana atau saluran komunikasi kepada komunikan yang tertuju sehingga dapat menimbulkan sebuah efek.

Pertumbuhan ekonomi yang relatif tinggi dan perubahan lingkungan yang cepat, seperti yang terjadi di Indonesia, menyebabkan perusahaan secara terus-menerus memantau pasar dan menyesuaikan diri terhadap perubahan pasar. Perusahaan kini 
harus memikirkan kembali misi bisnis dan strategi bisnis mereka secara kritis. Perusahaan masa kini tidak bergerak dalam pasar dengan saingan yang sudah diketahui dan sudah pasti, atau pilihan pelanggan yang stabil, melainkan perang antar saingan yang terus berubah.

Masyarakat modern saat ini memiliki ruang informasi yang sangat luas, hal ini disebabkan karena arus perkembangan teknologi informasi yang terus berkembang seiring waktu. Berbagai industri bisnis saat ini dituntut untuk merencanakan strategistrategi bisnis produknya agar mampu menghadapi persaingan pasar. Untuk dapat bersaing di pasar global seperti sekarang ini, dibutuhkan strategi bisnis produk yang kreatif, variatif serta komunikatif yang dikemas melalui strategi komunikasi bisnis. Strategi komunikasi adalah paduan antara perencanaan komunikasi dengan manajemen komunikasi untuk mencapai tujuan yang telah ditetapkan (Effendy, 1990:32). Untuk mencapai tujuan tersebut strategi komunikasi harus mampu menunjukkan bagaimana operasionalnya secara praktis harus dilakukan. Jadi, strategi komunikasi adalah keseluruhan perencanaaan, taktik, cara yang akan dipergunakan guna melancarkan komunikasi dengan memperhatikan keseluruhan aspek yang ada pada proses komunikasi untuk mencapai tujuan.

\section{Tinjauan Pustaka}

a. Proses Membaca Foto

Proses membaca foto adalah sebuah proses untuk masuk ke dalam serangkaian hubungan tersembunyi dari suatu kekuatan yang membingungkan. Kekuatan tersebut berada di dalam gambar di depan mata, sehingga perlu untuk tidak hanya melihatnya sebagai gambar saja, akan tetapi juga membacanya sebagai permainan aktif dari bahasa visual (Clarke, 1997: 29). Selain itu, Clarke menegaskan suatu komponen dasar yang perlu digarisbawahi bahwa foto 
merupakan produk dari fotografer sehingga foto tidak pernah bisa lepas dari perspektif spesifik diri fotografer yang menyesuaikan wacana budayanya, baik dari sudut pandang estetis, politis maupun ideologisnya. Sejalan dengan itu, Roland Barthes (1981: 9) melihat ada tiga aspek yang terdapat dalam foto, yaitu operator, spectator dan spectrum. Dalam kaitannya dengan foto prewedding, operator adalah fotografer yang menghadirkan foto prewedding menjadi suatu bentuk material. Spectrum adalah pasangan calon pengantin yang menjadi objek foto, sedangkan spectator adalah orang yang memandang foto prewedding tersebut dan membangun pemaknaannya sendiri melalui perspektif masingmasing.

Teori ini menjadi penting untuk diterapkan dalam mendukung proses pembacaan foto prewedding karena Spectrum, yang pada teori pertama kurang mempunyai peranan dalam proses pencarian makna, menjadi terlibat secara aktif dalam proses penjabaran foto prewedding berdasarkan pengetahuan atas dirinya sendiri. Ekspresi lisan memerlukan interaksi dari audiens yang spesifik, pada waktu yang spesifik pula. Disajikan dalam suatu hubungan, menciptakan konteks untuk transmisi cerita, juga menjadi suatu pengingat bahwa subjek di dalam foto tersebut bisa menjadi teman berbicara (Edward, ibid: 42). Jadi di dalam konteks foto prewedding, pasangan yang ada dalam foto tersebut mempunyai peranan dan kemampuan untuk berbicara dengan audience-nya, bercerita tentang kisah dan kenangan serta alasan hadirnya foto tersebut menjadi bentuk material.

\section{b. Marketing Mix}

Komunikasi bisnis adalah komunikasi yang digunakan dalam dunia bisnis yang mencakup berbagai macam bentuk komunikasi, baik komunikasi verbal maupun nonverbal. Sebagai awal bahasan dalam komunikasi bisnis, maka 
akan dibahas antara lain bentuk dasar komunikasi yang mencakup komunikasi verbal dan nonverbal, proses komunikasi, sebab-sebab timbulnya kesalahpahaman dalam komunikasi, dan bagaimana cara memperbaiki atau meningkatkan komunikasi.

Dalam buku Hermawan Kertajaya yang berjudul On Marketing Mix mengutip bahwa Marketing mix hanyalah bagian dari aktivitas pemasaran sebuah perusahaan secara keseluruhan. Marketing mix baru sebatas elemen dari taktik pemasaran. Marketing mix merupakan taktik dalam integrasikan tawaran, logistik, dan komunikasi produk/jasa. Dengan marketing mix tidak hanya perlu membuat penawaran yang menarik, tetapi juga harus memikirkan taktik yang tepat dalam mendsitribusikan dan mempromosikannya.

Marketing Mix merupakan aspek yang paling terlihat dari sebuah perusahaan dalam aktivitas pemasaran. Jadi, sebenarnya marketing mix bisa dikelompokan menjadi dua bagian, yaitu penawaran (offering) yang berupa product dan price, serta akses (acces) yang berupa place dan promotion. Hermawan Kertajaya biasa menyebut marketing mix sebagaian creation tactic dari perusahaan, karena marketing mix merupakan perwujudan langsung dari diferensiasai konten konteks infrastruktur.

Dalam penerapan marketing mix, Hermawan Kertajaya menyimpulkan bahwa terdapat tiga macam marketing mix. Pertama, marketing mix yang bukannya mendukung strategi pemasaran lain, tetapi malah merusaknya. Marketing mix ini disebut destructive marketing mix selain tidak membangun value, juga tidak meningkatkan merek perusahaan. Kedua, marketing mix yang cenderung meniru taktik yang sudah digunakan oleh pesaing. Marketing mix ini disebut metoomarketing mix. Dan yang ketiga, marketing mix yang 
mendukung strategi pemasaran lainnya. Marketing mix ini disebut creative marketing mix dapat menguatkan nilai perusahaan.

Menurut Kotler (2000:18) Marketing Mix adalah "Campuran dari variabel- variabel pemasaran yang dapat di pergunakan oleh suatu perusahaan untuk mengejar tingkat penjualan yang diiginkan dalam pasar sasaran”. Pendapat ini menunjukkan bahwa variabel-variabel pemasaran dapat dikendalikan oleh perusahaan sehingga perusahaan dapat menyelaraskan variabel- variabel tersebut dalam upaya mencapai tingkat penjualan yang diinginkan. Philip Kotler mendefenisikan marketing mix atau bauran pemasaran sebagai: serangkaian variabel yang dapat dikontrol dan tingkat variabel yang digunakan oleh perusahaan untuk mempengaruhi pasaran yang menjadi sasaran. Keempat unsur atau variabel bauran pemasaran (Marketing mix) tersebut atau yang disebut four $p$ 's, adalah sebagai berikut:

1. Strategi Produk

2. Strategi Harga

3. Strategi Penyaluran / Tempat

4. Strategi Promosi

\section{Metodologi}

Penelitian ini menggunakan metode kualitatif dengan teknik pengambilan data secara indepth interview dan didukung dengan kajian pustaka buku dan jurnal penelitian terdahulu. Penelitian ini mengambil lokasi strategis di Yogyakarta. Data diperoleh melalui observasi dan wawancara dengan pelaku industri foto prewedding, pelaku prewedding, dan masyarakat. Analisis data yang dilakukan meliputi pengumpulan data, triangulasi, penyajian data, dan penarikan kesimpulan. 


\section{Hasil Penelitian}

Prioritas utama bagi pasangan calon pengantin untuk memilih foto preweddingnya berkaitan dengan pose, ekspresi wajah, bentuk fisik tubuh yang terekam dalam foto serta hal-hal yang berkaitan dengan teknis fotografi, meskipun hal yang terakhir ini jarang dikeluhkan oleh para pasangan calon pengantin dikarenakan hampir keseluruhan foto yang diberikan oleh fotografer telah melewati proses pemilihan yang terbaik, terutama secara teknis. Pose merupakan pola perilaku yang terdapat pada foto-foto yang melibatkan figure manusia di dalamnya. Ketika seseorang berpose secera fisik di depan kamera, maka berbagai aspek fisik yang meliputi raut wajah, arah pandang, posisi badan, kostum serta berbagai property yang dipakainya menyiratkan makna (non-fisik) tertentu kepada orang yang melihat hasil foto potret tersebut sebagai konsekuensi dari pose fisiknya (irwandi, 2012:9).

Kostum merupakan perwujudan keinginan dari pasangan calon pengantin untuk memberikan gambaran nyata atas apa yang digunakan oleh mereka agar bisa menjadi sosok imaginasi seperti yang mereka harapkan. Dalam pandangan ahli yang mempunyai perspektif union, cinta merupakan usaha untuk membentuk suatu perpaduan, yaitu kami (Helm, 2009). Foto prewedding menjadi langkah awal atau persiapan awal bagi pasangan calon pengantin untuk membangun kesadarn bahwa kehidupan mereka saat ini tidak lah sendiri lagi, melainkan mereka sudah menjadi bagian dan terikat union yang mereka buat, meskipun secara kelembagaan sosial mereka belum terikat secara resmi.

Selain memperhatikan pose dan kostum prewedding sebagai bentuk reproduksi image diri para konsumen foto prewedding, maka dari sisi pelaku industri fotografi membuat mekanisme agar industri foto yang mereka miliki tetap memiliki 
massa. Salah satunya dengan menggunakan marketing mix yang diterapkan disebagian besar pelaku insutri foto.

\section{a. Place}

Pemilihan lokasi merupakan nilai investasi yang paling mahal, sebab lokasi bisa dikatakan menentukan ramai atau tidaknya pengunjung. Lokasi usaha yang berada di pinggir jalan atau ditempat yang strategis cukup menyedot pengunjung untuk sekadar mampir. Memang untuk mendapatkan lokasi yang strategis memang mahal. Lokasi merupakan faktor yang penting dalam mencapai keberhasilan sebuah perusahaan, yaitu menyangkut antara lain good visibility, easy access, convenience, curb side appeal, parking.

Menurut Mc Daniel Tempat menunjukan berbagai kegiatan yang di lakukan perusahaan untuk menjadikan produk dapat diperoleh dan tersedia bagi perusahaan. Keputusan saluran akan mempengaruhi dua hal, yaitu jangkauan penjualan dan biaya. Setiap alternatif saluran yang dipilih jelas dipengaruhi unsur-unsur lain yang terdapat dalam bauran pemasaran perusahaan. Misalnya tujuan yang ingin dicapai, ciri-ciri pasar yang dijadikan sasaran dan karakteristik produk yang ditawarkan. Penilaian terhadap alternatif saluran didasarkan kriteria ekonomis, efektfitas dan pengendalian.

\section{b. Price}

Harga adalah satuan moneter atau ukuran lainnya termasuk barang dan jasa lainnya yang ditukarkan agar memperoleh hak kepimilikan atau pengguna suatu barang dan jasa (tjiptono, 2000). Harga juga merupakan pertimbangan yang penting dalam memilih. Faktor-faktor yang mempengaruhi harga yang diterapkan dalam sebuah perusahaan, adalah: hubungan antara permintaan dan penawaran, penurunan loyalitas konsumen, sales mix, harga-harga dalam persaingan, biaya overhead, aspek psikologis, kebutuhan untuk meraih laba. 
Cara menentukan harga yang tepat adalah dengan melihat harga jual pesaing sejenis, tentunya dengan kualitas. Kemudian, tetapkan harga jual produk tersebut sedikit lebih murah daripada harga jual produk pesaing sejenis agar konsumen mau mencoba produk yang ditawarkan. Tetapi harga jual bisa tidak selalu lebih rendah

\section{c. Product}

Produk adalah keseluruhan konsep objek atau proses yang memberikan sejumlah nilai manfaat kepada konsumen. Produk dalam bisnis sangat bergantung pada pengalaman. Produk dapat berupa paket yang lengkap yang terdiri dari produk, jasa, servis, dan kenyamanan yang memuaskan kebutuhan dan keinginan konsumen dan menciptakan kesan yang tidak terlupakan. Sedangkan unik berarti beda dalam bentuk pelayanan, interior, suasana atau apa saja yang bisa menarik perhatian konsumen. Supaya suatu produk atau jasa menarik perhatian (terlihat unik) maka harus kreatif, banyak ide, melakukan inovasi terbaru.

\section{d. Promotion}

Langkah kecil berupa promosi dalam berbagai cara untuk meraih target pemasaran yang belum di raih. Promosi adalah aktivitas yang dilakukan perusahaan untuk mencari konsumen, bukan hanya untuk sekali datang, tetapi juga konsumen yang akan melakukan pembelian berulang (pelanggan). Tujuan dari promosi adalah meningkatkan awareness meningkatkan persepsi konsumen, menarik pembeli pertama, mencapai persentase yang lebih tinggi untuk konsumen yang berulang, menciptakan loyalitas merek, meningkat-kan average check, meningkatkan penjualan pada produk tertentu atau waktu- waktu khusus, dan mengenalkan produk baru. Cara promosi yang dapat dilakukan antara lain 
dengan promosi mounth by mounth, mengikuti event- event tertentu, mengadakan diskon kusus pada saat tertentu, memberi member card pada pelanggan. Dapat juga dilakukan melalui promosi seperti reklame, sisipan pada koran dan media massa atau menggunakan spanduk. Selain itu membuat konsep perusahaan yang unik dan disukai oleh pelanggan.

Kebijakan pembauran pemasaran tentu akan lebih berhasil jika apa telah diprogram dikomunikasikan dengan tertara yang baik. mengkomunikasikan program perusahaan kepada masyarakat konsumen dapat dilakukan dengan empat variabel, yaitu:

1) Periklanan: Bentuk presentasi dan promosi non pribadi tentang ide, barang, dan jasa yang dibayar oleh sponsor tertentu.

2) Personal selling: Presentasi lisan dalam suatu percakapan dengan satu calon pembeli atau lebih yang ditujukan untuk menciptakan penjualan.

3) Publisitas: Pendorong permintaan secara non pribadi untuk suatu produk, jasa atau ide dengan menggunakan berita komersial di dalam media mass dan sponsor tidak dibebani sejumlah bayaran secara langsung.

4) Promosi penjualan: Kegiatan pemasaran selain personal selling, periklanan dan publisitas yang mendorong pembelian konsumen.

\section{Diskusi}

Gagasan yang memposisikan foto sebagai ruang representasi, menjadi pintu masuk bagi industri foto yang tidak hanya memperkokoh mitos tentang komoditas ruang representasi ini, tetapi juga membangun dan membentuk imajinasi baru tentang pentingnya individu memiliki serta mengakomodasi ruang representasi yang lebih privat, bersifat individualis dan menekankan posisi ke-aku-an pasangan. Foto 
prewedding tidak hanya memisahkan diri mereka dari kepentingan keluarga maupun kuasa orang tua. Logika ekonomi dari industri foto yang menjadi dasar terbentuknya tren foto prewedding, mereduksi sisi kolektivitas hubungan keluarga yang biasanya terbangun melalui acara pernikahan dan menciptakan sifat individualis selain juga memperkuat sisi narsistik seseorang.

Keluarnya foto prewedding ke wilayah publik, entah berwujud undangan atau dipasang di gedung pernikahan, bukan hanya menegaskan identitas pasangan pengantin, tetapi juga memberikan penekanan terhadap kepemilikan keseluruhan acara pernikahan tersebut sedikit menggeser peranan orang tua dan keluarga besar sebagai tuan rumah bersama persta pernikahan dan menegaskan posisi pasangan pengantin dengan lebih jelas dan nyata dalam acara tersebut. Dalam prespektif ini, bisa dilihat bagaimana foto prewedding menciptakan kemungkinan adanya gesekan yang bisa menimbulkan konflik tersembunyi, pertentangan yang diam antara pasangan dengan orang tua dan keluarga besarnya. Apa yang menjadi keberatan orang tua bukan terletak pada pembuatan maupun kehadiran foto prewedding dalam acara pernikahan anaknya. Keberatan mereka muncul ketika foto prewedding dengan pose-pose mesra tersebut ditonton oleh banyak orang sehingga dikhawatirkan akan memancing penilaian buruk dari orang yang menontonya.

Promosi merupakan salah satu variabel dalam marketing mix yang sangat penting yang dilaksanakan oleh perusahaan dalam memasarkan suatu produk atau jasa. Kegiatan promosi bukan saja sebagai alat komunikasi antara perusahaan dengan konsumen, tetapi juga sebagai alat untuk mempengaruhi konsumen dalam kegiatan pembelian suatu produk atau penggunaan jasa yang sesuai dengan keinginan dan kebutuhan konsumen. 
Dalam insudtri fotografi bukan hanya menerapkan strategi komunikasi bisnis terhadap konsumen, tapi juga menerapkan marketing mix sebagai strategi komunikasi bisnis untuk mencapai tujuan pemasaran, dan sebagian besar pelaku industri foto tidak hanya juga menekankan marketing mix saja melainkan keahlian berkomunikasi yang baik, karena dengan berkomunikasi yang baik dapat membantu untuk meningkatkan jasa atau produk yang ada dengan menarik minat konsumen. Tetapi, tidak semua komunikasi yang dilakukan melalui tatap muka langsung dengan konsumen, adapun komunikasi yang sering dilakukan adalah melalui media. Media yang di gunakan adalah media sosial dan mesengger seperti facebook, instagram, layanan sms, telepon, whats app dan web sebagai pelengkap.

\section{Kesimpulan}

Melalui uraian yang dijelaskan diatas, dapat ditemukan beberapa kesimpulan sebagai berikut. Kehadiran tren pemakaian foto prewedding tidak terlepas dari pelebaran bisnis foto pernikahan yang dilakukan oleh para pelaku industri foto ini. Peralihan teknologi perekaman dari analog ke digital, memungkinkan para pelaku industri foto pernikahan untuk melakukan eksplorasi dan menciptakan wilayah komersial yang baru. Hasrat narsistik manusia yang selalu menginginkan tampilan terbaik dalam media representasinya serta ketertarikan masyarakat umum untuk mengabadikan acara penting keluarga ke dalam media foto, seperti acara pernikahan, menjadi celah yang dimanfaatkan oleh industri foto untuk masuk ke wilayah privat dari individu. Para pelaku industri foto kemudian menawarkan media representasi yang seolah mampu menampung dan membentuk wujud kesempurnaan diri serta mampu memfasilitasi ruang privat, keluar dari kuasa keluarga dan orangtua pada saat pernikahan dalam wujud foto prewedding. 
Pasca tahun 2000, di dorong oleh agresifitas industri fotografi, foto prewedding menjadi tren bagi para pasangan calon pengantin di kota-kota besar di Indonesia. Perspektif ekonomi dari industri foto yang melihat pasangan calon pengantin sebagai komoditas serta dibantu oleh masifnya konsumsi dan produksi foto prewedding di masyarakat, membentuk pola visual dari semua komponen atau unit yang hadir dalam setiap foto prewedding menjadi seragam. Komponen-komponen dari foto prewedding itu sendiri meliputi pose, kostum, latar maupun proses editing yang dilakukan pada pembuatan foto prewedding.

Meskipun begitu, seperti yang dipertanyakan dalam judul penelitian ini, apa yang ditampilkan di dalam foto prewedding membuat diri pasangan calon pengantin muncul bukan sebagai dirinya. Kegagalan medium foto untuk menampilkan kedua sisi dari kehidupan serta didukung oleh gagasan yang meletakkan medium ini sebagai bukti atas kenyataan yang terpercaya, membawa implikasi terhadap kemunculan ide bahwa hidup yang layak untuk ditampilkan hanyalah seputar pada kehidupan yang berasaskan pada kegembiraan, keceriaan dan segalaungkapan yang mendukung perasaan tersebut. Sehingga gambaran diri yang mereka dapatkan bukan hanya keluar dari keseharian mereka, tetapi sebuah citra yang dipoles dan dilebih-lebihkan agar menjadi 'sempurna' bagi pandangan pribadi serta tatapan orang lain. Kalaupun gambaran diri tersebut harus mengambil bagian dari aktivitas keseharian, maka haruslah mengambil potongan keseharian yang indah dan terbaik.

Citra kesempurnaan diri hanyalah ilusi yang dipermainkan dan dimanfaatkan secara maksimal oleh para pelaku industri foto untuk memperlebar ruang kerjanya. Kata modern sebagai isyarat untuk membuka diri dan hati serta deskripsi dari orang yang memandang keluar dan melihat sistem masyarakat pada waktu itu sebagai mekanisasi tanpa moderniasasi yang nantinya akan menghasilkan pemiskinan budaya 
(Mulder, 2007: 124), hari ini, melalui apa yang ditampilkan dalam foto prewedding mempunyai makna yang sebaliknya. Mengambil bagian dari aktivitas fotografi yang menjadi indikator sebagai modern, merupakan mekanisasi sosial yang dikontrol sepenuhnya oleh kuasa industri dan hasil akhirnya tidak pernah beranjak dari apa yang sebelumnya telah dibayangkan oleh Rendra sebagai masyarakat yang dimiskinkan secara budaya. Membuka diri bukan berarti membuka hati, dalam artian sebagai sikap kritis yang ditunjukkan terhadap apa yang diinginkan oleh seorang individu atas niat merepresentasikan diri dan memperoleh ruang privat dalam bentukan foto preweddingnya. Foto prewedding juga mampu meleburkan kelas sosial dalam masyarakat, karena foto prewedding dapat dijangkau semua kalangan masyarakat. Industri foto, melalui foto prewedding, merubah sistem nilai tradisional masyarakat dengan jalan memanipulasi perspektif dalam melihat dirinya dalam sebuah bingkai foto.

\section{Daftar Pustaka}

Abdullah, Irwan. 2006. Konstruksi dan Reproduksi Kebudayaan. Yogyakarta: Pustaka Pelajar

Ajidarma, Seno Gumira. 2002. Kisah Mata, Fotografi, antara dua subjek: Perbincangan antara ada. Yogyakarta: Galang Press

Barthes, Roland. 1981. Camera Lucida: Reflections on Photography. Terj. Richard Howard. New York. Hill and Wang

Barthes, Roland. 1984. Images-Music-Text. New York. Hill and Wang

Berger, John. 2002. The Ambignity of the Photography dalam Antropology of Media. Kelly Askew Noble and Edward Welch (ed). London and New York: Routledge

Clarke, Graham. 1977. The Photograph. Oxford New York: Oxford University Press

Edward, Elizabeth. 2009. Thinking Photography beyond the visual dalam Photography: theoretical snapshot. J.J Long. Andrea Noble and Edward Welch (ed). London and New York: Routledge 
Erlmann, veit. 2004. But what of the ethnographic ear? dalam hearing cultures. Essay on second, listening and modernity. Veit Erlmann (ed). Oxford. Berg

Frosh, Paul. 2003. The Imagery factory: consumer cultures, photography and visual content industry. New York. Berg

Helm, Bennet. 2009. Love dalam The Standford Encyclopedia og philosophy. Edward N Zatta (ed). http://plato.standford.edu/archives/fall2009/entries/love

Illouz, E. 1997. Constuming the romantic utopia. Love and the cultural contradictions of capitalism. Barkley: University of California Press.

Irwandi. 2012. Membaca fotografi potret: Teori, wacana dan praktek. Yogyakarta: Gama Media.

Jacobs. D.L. 1986. Domestic snapshots: toward grammar of motivies dalam intermedia: interpersonal communications in a media world. Gary gumpert and robert cathcart (ed). Oxford: Oxford University Press.

Kotler, Philip. Manajemen Pemasaran. Alih Bahasa Benjamin Molan Dan Hendra Teguh, Edisi Milenium, Jakarta, 2000.

Mudler, Neils. 2007. Di Jawa: Petualangan seorang antropolog. Terj. Sofia mansoor. Yogyakarta: Kanisius

O'brein, Michael E \& Norman Sibley. 1995. The photographic eyes: learning see with a camera. Massachusetts. Davis Publications, Inc.

Schroeder, Jonathan E. 2002. Visual Consumption. London and New York: Routledge.

Strasslerr, Karen. 2003. Reflected Vision: Popular Photography and the Indonesian cultures of documentation in postkolonial java. Unpublished Doctoral Desertation. The University of Michigan.

Suseno, Franz Magnis. 1991. Etika Jawa. Jakarta: PT. Gramedia Pustaka Utama.

Synott, Anthony. 2007. Tubuh sosial, simbolisme, diri dan masyarakat. Terj. Pipit Maizer. Yogyakarta dan Bandung: Jalasutra. 